\title{
The emergence of tropical medicine in Portugal: The School of Tropical Medicine and the Colonial Hospital of Lisbon (1902-1935)
}

\author{
Isabel Amaral \\ Centro de Investigação em História e Filosofia da Ciência e da Tecnologia. imsp-amaral@fct.unl.pt
}

Dynamis

[0211-9536] 2008; 28: 301-328
Fecha de recepción: 12 de diciembre de 2006

Fecha de aceptación: 26 de diciembre de 2007

SUMMARY: 1.--Introduction 2.-The emergence of tropical medicine in Europe. 3.-Tropical medicine at the Lisbon School of Tropical Medicine and the Colonial Hospital. 3.1.-Teaching and research 3.2.- The scientific missions: contact with endemic zones. 3.3.-Clinical activity. 4. Some concluding remarks.

ABSTRACT: The School of Tropical Medicine was founded in 1902 along with the Colonial Hospital of Lisbon. The Portuguese government recognized the importance of colonising the tropics and therefore supported the creation of a specific locus of medical training that would prove to be crucial to the clinical and experimental study of tropical diseases. This paper examines the importance of such institutions for the emergence of a new scientific area of research while also functioning as a consolidation factor for the Third Portuguese Colonial Empire. The creation of a new concept of medical practice with respect to tropical diseases characterizes a specific aspect of colonization: it underlies and drives the discourse of colonization itself. Consultation of data collected by the Portuguese Tropical School and the Colonial Hospital during the period between 1902 and 1935, the starting point of the present study, seeks to shed light on the ongoing debate concerning the history of tropical medicine within European colonial discourse.

PALABRAS CLAVE: Historia de la medicina tropical, medicina tropical portuguesa, Escuela de Medicina Tropical de Lisboa, Hospital Colonial de Lisboa.

KEYWORDS: History of Tropical Medicine, Portuguese Tropical Medicine, Lisbon School of Tropical Medicine, Colonial Hospital of Lisbon. 


\section{Introduction}

For European doctors in the nineteenth century, tropical medicine was virtually synonymous with military medicine. This association helps to explain why the progress of tropical medicine and the conquest of the empire in the tropics are often linked. Tropical medicine is also often employed as synonymous with imperial medicine or colonial medicine; however, each one of these designations conveys different meanings. Tropical medicine and imperial medicine approach the theme of empire and its possessions in the tropics in terms of unities of analysis ${ }^{1}$ whereas colonial medicine ${ }^{2}$ is fundamentally linked to the history of colonial expansion ${ }^{3}$.

This paper focuses on tropical medicine as an emergent scientific field of research ${ }^{4}$ at the end of the twentieth century ${ }^{5}$ and seeks to shed

1. See Curtin, Philip. Disease and Empire: the health of European troops in the conquest of Africa. Cambridge: Cambridge University Press; 1998. Palladino, Paolo; Worboys, Michael. Science and Imperialism. Isis. 1993; 84: 91-102.

2. For a more detailed analysis of Portuguese colonial medicine practices, see, for example, the publications on the Medical School of Goa, the oldest Portuguese colonial medical school: Bastos, Cristiana. O ensino da medicina na Índia colonial portuguesa: fundação e primeiras décadas da Escola Médico-Cirúrgica de Nova Goa. História, Ciências, Saúde-Manguinhos. 2004; 11 (supl. 1): 11-39; Figueiredo, João. A Escola Médica de Goa e o Ultramar Português. O Médico. 1954; 149: 1-6 (separata); Corrêa, Alberto. História do Ensino Medico na India Portuguesa. Nova Goa: Imprensa Nacional; 1917; Gracias, Fátima. Health and Hygiene in Colonial Goa (1510-1961). New Delhi: Xavier Centre of Historical Research-Concept Publishing; 1994; Figueiredo, João. Escola Médico-Cirurgica de Goa: esboço histórico. Arquivos da Escola Médico-Cirúrgica de Goa, série A. 1960; 33: 119-237; Figueiredo, João. Actividade da Escola Médico-Cirurgica de Goa, 1926-1950. Goa: Tipografia Fernandes; 1950; Bombarda, Miguel. Escola de Nova Goa. A Medicina Contemporânea. 23 Mar 1902; 2 (5); Mello, Froilano. History of Medicine in Portuguese India. Arquivos Escola Medico-Cirurgica Nova Goa, série B. 1930; 2: 723-730; and Pandya, S.K. Medicine in Goa: a former Portuguese territory. Journal Postgraduated Medicine [serial publication in internet]. 1982; 28: 123-148.

3. Arnold, David, ed. Warm climates and western medicine: The emergence of tropical medicine 1500-1900. Amsterdam: Rodopi; 1996.

4. Worboys, Michael. The emergence of tropical medicine: a study in the establishment of a scientific speciality. In: Lemaine, Gerard; MacLeod, Roy; Mulkay, Michael, eds. Perspectives on the emergence of scientific disciplines. Mouton: The Hague; 1976, p. 75-98.

5. Arnold, David, ed. Imperial medicine and indigenous societies. Manchester: University Press; 1988; Macleod, Roy; Lewis, Milton, ed. Disease, medicine and empire: Perspectives on Western medicine and the experience of European expansion. London: Routledge; 1988; Haynes, Douglas. From periphery to the centre: Patrick Manson and the development of tropical medicine in Great Britain, 1870-1900. [doctoral thesis]. University of California; 1992 
light on the spirit of the European imperialist era ${ }^{6}$ within the Portuguese context.

The beginning of the «Third Portuguese Empire» — characterized by the shift towards Africa- was a direct consequence of Brazil's independence in $1822^{7}$. Thereafter, Portugal administered the colonies which had for centuries been under its control: Angola, Mozambique, S. Tome and Principe, Guinea, and the Cape Verde, in Africa, and also Goa, Damão and Diu, in India.

Due to the growing interest of the European Powers in Africa at the end of the nineteenth century, Portugal soon realized that political policies with regard to Africa needed to be redefined; the growing presence of English, French, German and Belgian interests were threatening the traditional Portuguese hegemony over the coasts of Angola and Mozambique. Asserting its territorial rights based on primacy of European settlement, Portugal claimed various areas of the African continent although it in fact controlled only coastal outposts and a correspondingly limited hinterland. Thus, the Lisbon Geographic Society elaborated the «pink map» (mapa cor-de-rosa), a document representing the sovereignty of the territories binding Angola to Mozambique, in a region which at present corresponds to Zambia, Zimbabwe and Malawi. Following the conference of Berlin (initiated in 1884) which divided Africa in accordance with European colonial interests, England presented Portugal with an ultimatum in 1890, proclaiming that the colonies should be permanently occupied. As a result, Portugal encouraged a nationalist feeling, thus contributing to the redefinition of the imperial system. As a result, a programme of settlement of the territorial frontiers by the military and an intensive deployment of the colonial enterprise replaced the previous imperial regime based on the political and social domination of these overseas possessions by indigenous elites

6. Beyond the European context, specifically in the American context, authors such as Marco Cueto or Warwick Anderson would be mandatory references. However, due to methodological reasons, only the European model of tropical medicine is here considered. See, for example, Anderson, Warwick. Colonial pathologies: American tropical medicine, race, and hygiene in the Philipines. London: Duke University Press; 2006; and Cueto, Marcos. El regreso de las epidemias. Salud y sociedad en el Perú del siglo XX. Lima: Instituto de Estudios Peruanos; 1997.

7. For an overview of the political influence of Portugal in Africa since the independence of Brazil see, for example, Valentim, Alexandre. Vellho Brasil, Novas Áfricas: Portugal e o Império (1808-1975). Lisboa: Edições Afrontamento; 2000. 
up to that moment ${ }^{8}$. Portugal's imperial interests were therefore confined to those ties it succeeded in maintaining between metropolis and colonial territories. The redefinition of its imperial system led subsequently to the creation of wealth and national progress.

Between 1902 and 1935, the period analysed in this article, Portugal underwent a transition through three types of political regimes: from a monarchy to a republic in 1911 and from a republic to a dictatorship in 1932. The final period of the Portuguese monarchy (overthrown in 1910) and the First Republic (1910-1926) endeavoured to maintain its control over its African possessions. Nonetheless, it was only with the dictatorial regime under António Salazar (1926-1974) that Portuguese colonialism would be established in the modern sense of the term, namely, as the interplay of institutions, knowledge acquisition and a particular order of discourse 9 .

Notwithstanding the differences underlying the political practices of each of these regimes, the nationalist wave had always been present and had grown in determination. Concurrently, colonial imperialism never ceased being a guiding force in orientating, organizing and supporting the development of tropical medicine as a medical speciality crucial to the expansion of the empire.

As the European imperial powers mobilized themselves to colonize the less «civilized» regions of the globe, Portugal's predominance in the specialized area of tropical medicine became a driving force of the Third Colonial Empire. Despite its general state of national decline, Portugal had never broken ties with its main political partners, namely, the other European empires, and maintained a close relationship with them not only in political terms but also and specifically in scientific terms.

\section{The emergence of tropical medicine in Europe}

Tropical medicine emerged as a new disciplinary field at the beginning of the twentieth century as a result of the convergence of a set of factors

\footnotetext{
8. For an economic analysis of the Third Portuguese Colonial Empire, see Clarence-Smith, Gervase. The Third Portuguese Empire, 1825-1975: A study in economic imperialism. Manchester: Manchester University Press; 1985.

9. Thomaz, Omar. Ecos do Atlântico Sul: Representações sobre o terceiro império colonial português. Rio de Janeiro: Universidade Federal do Rio de Janeiro; 2002.
} 
comprising not only cognitive aspects but also the entire social setting. The problematic emergence of new disciplines or scientific specialities has been given serious academic attention since the seventies by sociologists and historians ${ }^{10}$ as well as by epistemologists of science ${ }^{11}$. However, a full account of the disciplinary emergence of the field of tropical medicine as a specific discipline has yet to be made and remains to this day outside the scope of established interpretive models although they certainly overlap. For instance, the influence of the political agenda at the centre of the European expansionist ideology was decisive for the cognitive development of the discipline in question. Our present analysis of the process of emergence of a new discipline focuses mainly on the study of the institutions of teaching, investigation and clinical practice where this new discipline came to acquire the status of an autonomous discipline, practiced by military physicians in the colonies, with a specific object of study, a specific language and a specific methodology distinct from general medicine ${ }^{12}$.

From the scientific point of view, knowledge about tropical diseases became defined, both from an etiological perspective and with respect to their transmission mechanisms, through the work of Alphonse Laveran (1845-1922) in 1880, and Patrick Manson (1844-1922) in 1887, both of whom worked within the framework of a Pasteurian conceptualization of disease. However, the scientific community soon became involved in explicating

10. Amidst the various theoretical approaches in the fields of sociology and the history of science for the analysis of emerging disciplinary areas, the following illustrative texts are of value: Lemaine; MacLeod; Mulkay, n. 4, p. 75-98; and Geison, Gerald. Scientific change, Emerging specialties, and research schools. History of Science. 1981; 19: 20-40. In the Portuguese case, the research school of Marck Athias was the object of a larger investigation with respect to the emergence of biochemistry in Portugal. For further details, see Amaral, Isabel. The emergence of new scientific disciplines in Portuguese medicine: Marck Athias's Histophysiology research School, Lisbon (1897-1946). Annals of Science. 2006; 63: 85-110; and Amaral, Isabel. As escolas de investigação de Marck Athias e de Kurt Jacobsohn e a emergência da Bioquímica em Portugal. Lisboa: Fundação Calouste Gulbenkian; 2006.

11. Caponi, Sandra. Coordenadas epistemológicas de la medicina tropical. História, Ciências, Saúde -Manguinhos. 2002; 10 (1): 113-149.

12. For the Portuguese case see the most emblematic synthesis elaborated by Carlos Vieira Ramos, a military physician, analysing the evolution of the Health Public Services in Portugal since the fifteenth century. The author emphasizes the teaching and the clinical training of the military physicians, in two volumes. With respect to the colonial war, see Ramos, Carlos Vieira. História da Medicina Militar Portuguesa. Vol. II, Lisboa: Estado Maior do Exército; 2004. p. 109-388, 511-589. See also several articles written by the Navy physician, Rui Abreu, for the Army Journal (Revista da Armada), an army Portuguese journal published since 1848. 
the variables that might lead to the eradication of those diseases affecting colonists and those affecting the indigenous people in the colonies under European rule (malaria, sleeping sickness, yellow fever, etc.). European powers sought to consolidate colonial rule, and health care lay at the heart of every foreign policy. Chamberlain's (1836-1914) exemplary declaration, «the fight against tropical diseases constitutes the real basis of the politics of colonization», found political expression in the inauguration of the Liverpool School of Tropical Medicine ${ }^{13}$, the first to be opened in Great Britain. The Schools in London in $1899^{14}$, the Pasteur Institutes overseas after $1900^{15}$, the school of Hamburg (Hamburg Institut für Tropenmedizin) and Marseilles (École du Pharo), in 1905, those of New Orleans (Medical College of Tulane University School of Medicine), and Portugal, in $1902^{16}$, that of Brussels in 1906 (Institut de Médecine Tropicale), and, finally, that of Amsterdam (Koloniaal Instituut), in 1910, soon followed.

The support lent to this type of institution by the imperial powers led to the creation of colonial medical services by governments and the concomitant involvement of the medical community in this speciality. Consequently, two complementary institutions cooperated in the emergence of this speciality: the schools and the hospital.

In 1901, Miguel Bombarda (1851-1910), one of the most influential doctors and politicians to favour a progressive mentality, defended the urgency of Portugal's participation in the medical colonisation movement, in ways similar to what had already taken place in other European countries, as can be seen in a communication delivered by him at the Society of Medical Services in Lisbon:

13. For a more detailed account of this institution, see Power, Helen. Tropical medicine in the twentieth century: A history of the Liverpool School of Tropical Medicine, 1898-1990. London: Kegan Paul International; 1999.

14. For more about the history of this British medical school, see Wilkinson, Lise; Hardy, Anne. Prevention and cure: The London School of Hygiene and Tropical Medicine, a 20th Century quest for global public health. London: Kegan Paul; 2001.

15. The rapid diffusion of Pasteur Institutes throughout the world, as a result of the influence of Pasteurian science, is crucial to the emergence of tropical medicine and its specialization. See Moulin, Anne Marie. Patriarchal science: The network of the overseas Pasteur institutes. In: Petijean, Patrick; Jamie, Catherine; Moulin, Anne Marie. Sciences and Empires, London: Kluwer Academic Publishers; 1992, p. 307-322.

16. See Ribeiro, Pedro. A emergência da Medicina Tropical em Portugal (1887-1902). [Doctoral thesis]. Universidade Nova de Lisboa; 2002. 
«Colonisation is not only a social and economic question but also a question of hygiene and pathology. The prosperity and wealth of a colony depend, first of all, on the ease of the living conditions to be found there by the colonists. The remedy to the serious risks presented by colonization undertaken blindly lies in the intervention of medicine together with the highly powerful resources that are currently available. England, Germany and France have demonstrated their recognition of this reality by creating centres for study and teaching that can easily be converted into colonial well-being and colonial prosperity» ${ }^{17}$.

The Portuguese government heeded Miguel Bombarda's appeal. The Minister of Maritime and Overseas Affairs, António Teixeira de Sousa (1857-1917), proposed the creation of the Lisbon School of Tropical Medicine (Escola de Medicina Tropical de Lisboa) ${ }^{18}$, and on the 24th of April 1902, King D. Carlos I (1863-1908) decreed the simultaneous creation of this institutions as well as the Colonial Hospital (Hospital Colonial de Lisboa $)^{19}$, in accordance with a proposal by the parliament ${ }^{20}$ :

«The proposal to create these institutions would not depend on public donation, as would happen in England and France, but would, in a modest way, prepare a building belonging to the navy for the teaching of tropical medicine and for the establishment of a hospital for the workers and soldiers returning from overseas. Teaching would be split into three disciplines: pathology and general medicine, hygiene and climatology, bacteriology and tropical parasitology, with the necessary laboratories. There would be a general course for the colonial doctors and lessons for the civilian workers, military personnel, missionaries, farmers and businessmen. Instruction would be carried out by the doctors of the overseas and naval permanent staff. The medical services of the hospital would be carried out by workers of the

17. Bombarda, Miguel. A creação d'uma escola de medicina colonial. Jornal da Sociedade de Ciências Médicas de Lisboa. 1901; 65 (10): 334.

18. In Portuguese historiography, a couple of works should be highligted as reference texts for studying the emergence of tropical medicine. Both of them are focused on the history of its major institutions, namely, the Lisbon School of Tropical Medicine, founded in 1902, and the succeeding institutes, the Institute of Tropical Medicine, between 1935 and 1942, and the Institute of Hygiene and Tropical Medicine, since 1942. See Fraga de Azevedo, João. Cinquenta anos de actividade do Instituto de Medicina Tropical. Lisboa: Instituto de Higiene e Medicina Tropical; 1952; Abranches, Pedro. O Instituto de Higiene e Medicina Tropical: um século de história 1902-2002. Lisboa: Instituto de Higiene e Medicina Tropical; 2004.

19. Decreto Lei de 24 Abril 1902.

20. Sessão Parlamentar de 26 Fevereiro 1902, p. 15. 
health bureau, without special remuneration. The auxiliary services would be undertaken by soldiers from the overseas health corps. Initial financing proposed an amount to sponsor the hospital that would be deducted from the discounts on the salaries of the personnel, from the registration fees and from the monies from the municipalities and municipal commissions from the colonies ( $1 \%$ of ordinary expenses). The cost of installation would be borne by the colonies».

For the foundation of the London School of Tropical Medicine, in 1899, Joseph Chamberlain, Minister of the British colonies, had appealed for a donation of all those who could support colonial issues. The voluntary contributions produced 16,000 pounds. Likewise, in Portugal, the Ministry of Colonies and Foreign Affairs donated 3,500 pounds; the Ministry of India, 1,000 pounds, and the remainder of the donation being covered by individuals and financial and commercial companies, in order to support the creation of the School of Tropical Medicine and the Colonial Hospital, in Lisbon ${ }^{21}$.

The necessary conditions for turning tropical medicine into one of the most powerful tools of the Third Portuguese Colonial Empire, among which the Colonial Hospital was a crucial element, were now in place.

The School's objectives were the «theoretical and practical teaching of tropical medicine» and the organization of the «scientific missions to the overseas provinces and the foreign colonies» while the hospital was intended to serve as a place of «treatment of soldiers returning from overseas». In Portugal, the conditions were in place for recognizing that the fight against tropical diseases was essential to the efforts of colonization. Concurrently, the scientific missions were now seen as a prerequisite for the establishment of endemic maps ${ }^{22}$, which were crucial to the eradication of exotic diseases in the colonized territories, as attested by the affirma-

21. Sessão Parlamentar de 28 Janeiro de 1902, p. 18.

22. Knowledge on the geographic conditions in the Portuguese colonies enabled the elaboration of maps of the main endemic zones comprising various tropical diseases, such as sleeping sickness and malaria, both transmitted by insects. Such endemic mapping, well known to the international scientific community, permitted, therefore, the evaluation of the proliferation of tropical diseases together with the description of their territorial delimitation, so as to control these endemic diseases. In such cases, the study missions, organized by different European schools of tropical medicine, constituted the real basis of colonial expansion. 
tions of João Fraga de Azevedo (1906-1977), one of the directors of this institution, years later ${ }^{23}$ :

«The participation of the School of Tropical Medicine in the colonization and civilization of overseas territory (...) was achieved through the intervention of the doctors who had specialized in teaching the profession at the School of Tropical Medicine, through study missions and through dissemination and research work».

In order to analyse the emergence of medicine in Portugal, one should frame the cognitive development of the discipline in relation to its respective institutional and political contexts. Thus, we will discuss the genesis of the discipline by taking into account the history of institutions (the school and the hospital), analysing the scientific features of its research as well as educational and clinical practices in the context of Portuguese colonial ideology. We will highlight the role of scientific missions, a key element in the scientific dynamics of the school and the hospital, in comparison with the criteria followed by other European colonising countries.

\section{Tropical medicine at the Lisbon School of Tropical Medicine and the Colonial Hospital}

The history of tropical medicine in Portugal centres on the aforementioned School and Hospital. As we shall see, both institutions represent not only be the basis for the emergence of a new disciplinary area in the lexicon of Portuguese medical courses, but also represent the two state-run institutions by way of which Portugal achieves an effective and viable programme of colonization in Africa. The school centred on teaching, research and the organization of scientific missions; the hospital became the locus of investigation in the field of clinical practice in partnership with the School's laboratories.

23. For a general understanding of the beginnings of tropical medicine in Portugal, see Fraga de Azevedo, n. 18, p. 10-97. 


\subsection{Teaching and research}

The teaching of, and research in, Portuguese tropical medicine date back to 1887 , specifically to the Navy School, promoted by Henrique de Barros Gomes (1843-1898), minister of Foreign Affairs and minister of Navy and the Overseas Territories ${ }^{24}$. This School began to teach two disciplines: Exotic Pathology and Naval Hygiene. Here, some tropical medicine subjects were taught to medical students in general; these subjects were taught as a speciality to navy physicians. Research was headed by Ayres Kopke (19021936) and his collaborators. Some diagnostic tests were performed in a small laboratory at this institution. However, tropical medicine was only recognized in its own right in 1902 when the Lisbon School of Tropical Medicine was founded to join its European counterparts.

In 1902, when the Lisbon School of Tropical Medicine was created, the medical course was constituted by three disciplines: clinical and exotic pathology, hygiene and climatology, and bacteriology and parasitology. This disciplinary division was very similar to the programmes organized in the London ${ }^{25}$ School. Funding came from the overseas provinces. The School was also responsible for teaching a secondary course in tropical hygiene for missionaries, officials, businessmen, farmers, teachers, and all those interested to go to Africa. The School was responsible for the publication of a specialized periodical which represented the repository for research carried out at the School as well as by teachers and researchers of the School at work in the different overseas provinces. This periodical, «Archives of Hygiene and Exotic Pathologies» (Archivos d'Hygiene e Patologia Exoticas), was published between 1905 and 1925 and later replaced by the «Annals of the Institute of Tropical Medicine» (Anais do Instituto de Medicina Tropical) in 1935.

In response to the growing interest in tropical medicine and the growing number of students at the School, the first curricular reform was approved in 1920. The course was then re-organized into four disciplines: climatology and geographic medicine, hygiene and bacteriology, general medicine and

\footnotetext{
24. Decreto Lei de 25 de Agosto de 1887.

25. See the Syllabus published by The London School of Tropical Medicine and the Seaman's Hospital printed by E. G. Berryman \& Sons Stream Works Blackheath Road S:E, since 1899 to 1925.
} 
pathology, parasitology and entomology. The costs regarding personnel were covered by the government, while the equipment, full-time and guest medical staff, publications and missions were funded by the School itself. After the Colonial Hospital had been relocated to another building, the School then had access to more space. The conditions found on the new premises were significantly improved and three laboratories came into existence (bacteriology, parasitology, and clinical analysis, respectively), all of them headed by Kopke.

This centre for teaching and specialized medical research was active on several fronts in the combat against exotic diseases both in the tropics and on the continent. During this period, the work that was most representative of the guidelines for intervention in the management of colonial medicine in the tropics was published in the "Archives of Hygiene and Exotic Pathologies». The school operated as an agency for specialized technical training and fundamental research as well as a support to specialized diagnoses that were too difficult to carry out in the colonies.

Besides the school, there were sanitation centres located in the various Portuguese colonies led by doctors who had specialized at the Lisbon school. These doctors were responsible for the organization of sanitary services in the colonies, having as their prime goal the creation of a technical council with specific responsibilities; the study of the most widespread diseases in the colonial provinces; the creation of means for technical progress for the professionals involved (doctors, pharmacists, nurses); the creation of ways to finance the equipment of the laboratories and the colonial hospitals; the creation of provincial laboratories, and, finally, the creation of specialized journals to be published in the colonies.

The scope of the publications authored by the medical staff at the Lisbon School of Tropical Medicine encompassed the following areas: the teaching of colonial medicine; research on different exotic diseases (sleeping sickness, malaria, tuberculosis, studies of helmintology and parasitology, leishmaniosis); research on vectors (trypanosome); entomological studies (the identification of glossines, anopheles); prophylactic tests (sleeping sickness, malaria); the mapping of endemic diseases in the various colonies (sleeping sickness, beriberi, plague), and reports by the study missions undertaken in overseas provinces.

The London and Liverpool Schools of Tropical Medicine, in Britain together with the Marseille School of Tropical Medicine, in France, received these publications and made their own publications available to the Lisbon 
school. However, given that the former publications were mainly written in Portuguese, their dissemination was limited.

\subsection{The scientific missions: contact with endemic zones}

Among the great contributions to the field of tropical medicine, we must reflect on a typically African disease, sleeping sickness ${ }^{26}$, with regard to which the researchers of the Lisbon School of Tropical Medicine were to achieve considerable notoriety. In the twentieth century, sleeping sickness had become the main obstacle to the economic development of the colonies. Portugal joined other European countries, all of whom were participants in a European alliance seeking to combat trypanosomiasis by creating conditions of effective control both in the metropolis and in the colonies. Each country invested in basic research, training of specialized staff, participation and continuous dialogue with the international scientific community, and the organization of scientific missions. The scientific missions undertaken by the Lisbon school between 1902 and 1935 reveal the importance this exotic pathology held both for Portuguese national interests and as a civilizing force.

Eight missions were undertaken, six of which dealing with sleeping sickness: those to the Island of Principe in 1904, 1907 and 1911; to Mozambique in 1910 and 1927; and to Guinea in 1932. The remainder were missions to gather material for the museum collection of entomological species and also for sanitation planning in the province of Cape Verde, as can be seen in table 1:

26. Sleeping sickness is an African disease caused by protozoa of the genus Trypanosome and transmitted by the tsetse fly. This disease is extremely contagious and can decimate entire regions in a short period of time. The lymph nodes become greatly enlarged and lead to the degeneration of the central nervous system, which in turn provokes symptoms of profound fatigue, thus the name sleeping sickness. This disease concerned all colonising empires because it threatened the settlement of colonists and effective colonisation due to the lack of sufficient, healthy indigenous labour. 
Table 1. Research of the School of Tropical Medicine and the study missions undertaken by the teaching staff between 1902 and 1935

\begin{tabular}{|c|c|c|c|c|c|}
\hline $\begin{array}{c}\text { Teachers } \\
\text { E Medical } \\
\text { Researchers } \\
\end{array}$ & $\begin{array}{l}\text { Principal } \\
\text { Subject of } \\
\text { Research } \\
\end{array}$ & $\begin{array}{c}\text { Disciples } \mathcal{E} \\
\text { Collaborators }\end{array}$ & $\begin{array}{c}\text { Specialized } \\
\text { Training }\end{array}$ & $\begin{array}{l}\text { Laborato- } \\
\text { rial Space }\end{array}$ & $\begin{array}{l}\text { Scientific } \\
\text { Missions }\end{array}$ \\
\hline Ayres Kopke & $\begin{array}{l}\text { Sleeping } \\
\text { Sickness } \\
\text { (identification } \\
\text { of transmitting } \\
\text { vector, } \\
\text { prophylaxis \& } \\
\text { treatment of } \\
\text { disease) }\end{array}$ & $\begin{array}{l}\text { Daniel Perdigão, } \\
\text { Correia Mendes, } \\
\text { Manuel Prates, } \\
\text { Firmino } \\
\text { Sant'Anna }\end{array}$ & $\begin{array}{l}\text { Visits to the } \\
\text { schools of } \\
\text { Liverpool, } \\
\text { London \& } \\
\text { Paris }\end{array}$ & $\begin{array}{l}\text { Colonial } \\
\text { Hospital }\end{array}$ & $\begin{array}{l}\text { Beriberi \& } \\
\text { Sleeping } \\
\text { Sickness } \\
\text { (Principe, 1904) }\end{array}$ \\
\hline $\begin{array}{l}\text { A. Correia } \\
\text { Mendes }^{27}\end{array}$ & $\begin{array}{l}\text { Sleeping } \\
\text { Sickness }\end{array}$ & $\begin{array}{l}\text { A. Villela, }{ }^{28} \\
\text { Bruto da Costa, }{ }^{29} \\
\text { Damas Mora }^{30}\end{array}$ & & & $\begin{array}{l}\text { Sleeping Sick- } \\
\text { ness, Island of } \\
\text { (Principe, 1907) }\end{array}$ \\
\hline $\begin{array}{l}\text { J. Firmino } \\
\text { Sant'Anna }\end{array}$ & $\begin{array}{l}\text { Sleeping } \\
\text { Sickness }\end{array}$ & & & & $\begin{array}{l}\text { Sleeping Sickness } \\
\text { (Mozambique, } \\
1910 \text { ) }\end{array}$ \\
\hline $\begin{array}{l}\text { A. Correia } \\
\text { Mendes }\end{array}$ & $\begin{array}{l}\text { Sleeping } \\
\text { Sickness }\end{array}$ & $\begin{array}{l}\text { Bruto da Costa, } \\
\text { P. Meira, } \\
\text { C. Andrade, } \\
\text { G. Vieira, } \\
\text { A. C. Santos, } \\
\text { A. Álvares, } \\
\text { F. Sant'Anna }\end{array}$ & & & $\begin{array}{l}\text { Sleeping Sickness } \\
\text { (Principe, 1911- } \\
\text { 1914) }\end{array}$ \\
\hline Ayres Kopke & $\begin{array}{l}\text { Sleeping Sickness } \\
\text { (identification of } \\
\text { transmitting vec- } \\
\text { tor, prophylaxis } \\
\& \text { treatment of } \\
\text { disease) }\end{array}$ & $\begin{array}{l}\text { Aníbal de } \\
\text { Magalhães, } \\
\text { Firmino } \\
\text { Sant'Anna, Fon- } \\
\text { toura Sequeira, } \\
\text { Saraiva de Aguillar, } \\
\text { Daniel Perdigão }\end{array}$ & & & $\begin{array}{l}\text { Sleeping Sickness } \\
\text { (Mozambique, } \\
\text { 1927) }\end{array}$ \\
\hline $\begin{array}{c}\text { José de } \\
\text { Magalhães }\end{array}$ & $\begin{array}{l}\text { Hemoglobinuric } \\
\text { Bilious Fever }\end{array}$ & Luis Fontoura & & & $\begin{array}{l}\text { Entomological } \\
\text { Study (S. Thome, } \\
1930)\end{array}$ \\
\hline
\end{tabular}

27. Aníbal Correia Mendes was the director of the Bacteriologic Laboratory of Luanda, Angola.

28. Arnaldo José Villela was the director of the Hospital of Praia, Cape Verde.

29. Bernardo Francisco Bruto da Costa was the director of the Bacteriological Laboratory, S. Tome.

30. António Damas Mora was the delegate of Health at the Island of Principe. 
Table 1. Research of the School of Tropical Medicine and the study missions undertaken by the teaching staff between 1902 and 1935 (continued)

\begin{tabular}{|c|c|c|c|c|c|}
\hline $\begin{array}{c}\text { Teachers } \\
\text { E Medical } \\
\text { Researchers }\end{array}$ & $\begin{array}{l}\text { Principal } \\
\text { Subject of } \\
\text { Research }\end{array}$ & $\begin{array}{c}\text { Disciples E } \\
\text { Collaborators }\end{array}$ & $\begin{array}{l}\text { Specialized } \\
\text { Training }\end{array}$ & $\begin{array}{l}\text { Laborato- } \\
\text { rial Space }\end{array}$ & $\begin{array}{l}\text { Scientific } \\
\text { Missions }\end{array}$ \\
\hline $\begin{array}{l}\text { J. Firmino } \\
\text { Sant'Anna }\end{array}$ & $\begin{array}{l}\text { Sleeping } \\
\text { Sickness }\end{array}$ & & & & $\begin{array}{l}\text { Mission of Sani- } \\
\text { tation Demogra- } \\
\text { phy (Cape Verde, } \\
1930 \text { ) }\end{array}$ \\
\hline $\begin{array}{l}\text { Luis } \\
\text { Fontoura } \\
\text { Sequeira }\end{array}$ & $\begin{array}{l}\text { Sleeping } \\
\text { Sickness }\end{array}$ & & & & $\begin{array}{l}\text { Study Mission } \\
\text { Sleeping Sickness } \\
\text { (Guinea, 1932) }\end{array}$ \\
\hline
\end{tabular}

Since its beginnings, the Lisbon School of Tropical Medicine saw its reputation recognized in Europe thanks to the contributions made by Ayres Kopke and by his research group with respect to the use of Atoxyl ${ }^{31}$ in the treatment of sleeping sickness. This fact had an immediate impact on the number of study missions undertaken by the various medical missions in service to the Portuguese government between 1902 and 1935.

The first missions on sleeping sickness targeted two of the richest Portuguese colonies, namely, the Island of Principe (1904, 1907 and 1911) and Mozambique (1910 and 1927).

The Island of Principe was a privileged region for a Portuguese scientific mission ${ }^{32}$. In 1904, Ayres Kopke led a preliminary exploratory mission. After 1907, the missions set more precise goals in accordance with

31. Atoxyl (p-aminophenylarsenic acid) is an arsenical derivative that was synthesized for the first time in 1859 by Antoine Béchamp. It was used by several authors for the treatment of syphilis and it was tested on laboratory animals. In 1905, Robert Koch discovered during an African expedition that Atoxyl could also be used to treat sleeping sickness. In 1906 Ayres Kopke announced his experimental results using Atoxyl and the subsequent treatment of patients with tripanosomiasis gambiense. Kopke, Ayres. Traitement de la maladie du sommeil. Archivos de Hygiene e Pathologia Exoticas. 1907; 1 (3): 299-349; Amaral, Isabel; Barreira, Conceição. Chemistry applied to medicine: the School of Tropical Medicine of Lisbon (19021935). Proceedings 5th International Conference on History of Chemistry. Lisbon: Sociedade Portuguesa de Química; 2006, p. 493-501.

32. The island had a reduced territorial extension and population. The majority of the population remained constant, which permitted long-term patient follow-up. 
the experimental research conducted by the Ayres Kopke ${ }^{33}$ group at the Lisbon School of Tropical Medicine: medical trials with Atoxyl and the adoption of prophylactic measures with a view to their application «in the continental part of the referred provinces» ${ }^{34}$. These missions had as their model the French mission led by A. Laveran in the Congo ${ }^{35}$. The mission of 1911, which was prolonged until 1914, had as its basis the elaboration of a prophylactic plan aiming at the eradication of the endemic disease on the island ${ }^{36}$. The results obtained by the various missions performed on the island were recognized by the international scientific community, and in particular, this final mission to the Island of Principe, which resulted in the eradication of the disease ${ }^{37}$.

The Portuguese Naval Military Club, recognizing the importance of these results for the development and official recognition of the field of tropical medicine in Portugal, promoted the issuing of a commemorative stamp. In this philatelic document, the symbols of Portuguese medicine in the first half of the twentieth century can be seen, based above all on experimental practice, of which the microscope was the emblematic instrument. Other elements visible refer to the new medical speciality, namely, tropical medicine, identified by the figure of Ayres Kopke and his intervention concerning the tsetse fly on the Island of Principe.

33. Corrêa Mendes, Aníbal; Silva Monteiro; Damas Mora, António; Bruto da Costa, Bernardo. Relatorio Preliminar da Missão de Estudo da Doença do Somno na Ilha do Principe. Archivos de Hygiene e Pathologia Exoticas. 1909; 2 (1): 3-45.

34. Instrucções para a missão médica encarregada do estudo da doença do somno na llha do Príncipe. Lisboa: Imprensa Nacional; 1907.

35. Martin, Gustave; Leboeuf, Alexandre; Roubaud, Emile. Rapport de la Mission d'Étude de la Maladie du Sommeil au Congo Français, 1906-1908. Paris: Masson \& Cia. Éditeurs; 1909.

36. Bruto da Costa, Bernardo. Relatorio-Trabalhos sobre a doença do somno na Ilha do Principe. Lisboa: A Editora Limitada; 1913.

37. These results were originally published in Portuguese in 1915, and in English — translated by John A. Wyllie - in 1916. See Bruto da Costa, Bernardo; Firmino Sant'Anna, José; Correia dos Santos, António; Araújo Alvares, M.G. Relatorio Final da Missão da doença do sono da Ilha do Príncipe. Arquivos de Higiene e Patologia Exóticas: 1915; 5, 1-250; Bruto da Costa, Bernardo; Firmino Sant'Anna, José; Correia dos Santos, António; Araújo Alvares, M.G. Sleeping Sickness: A record of four years' war against it in Principe, Portuguese West Africa. London: Baillière, Tindall and Cox; 1916. 


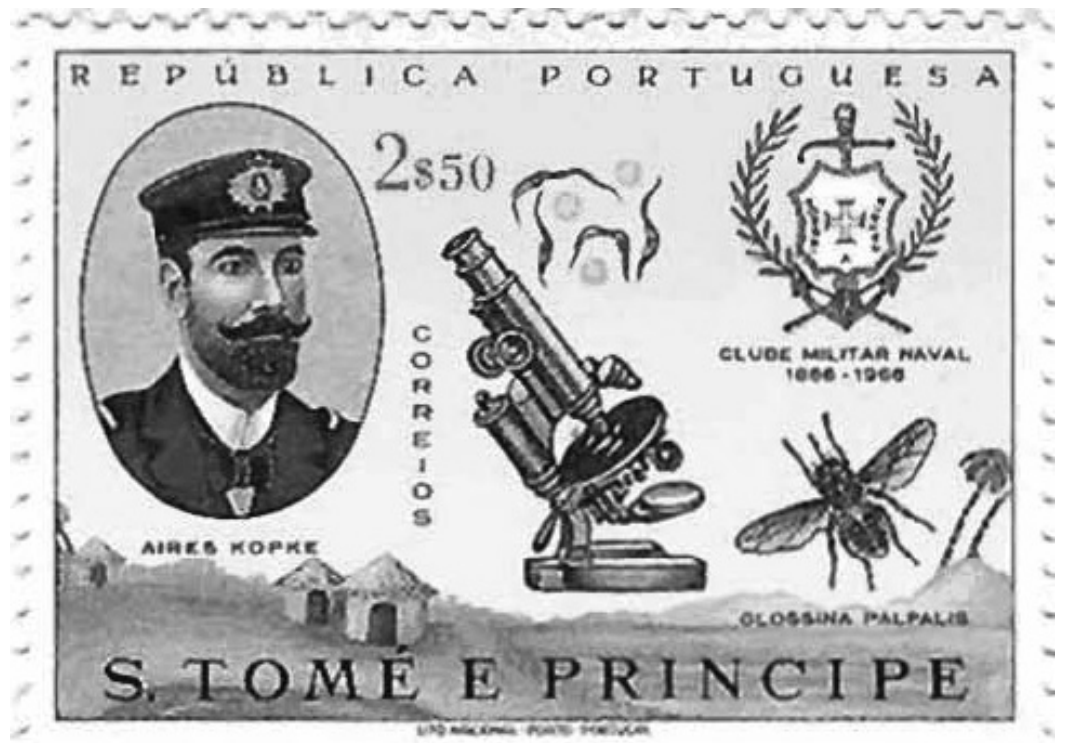

Figure 1. Commemorative stamp of the eradication of sleeping sickness in the Island of Principe (S. Tome) ${ }^{38}$

Two missions were carried out in Mozambique, the first in 1910, the second in 1927. The mission having the greatest impact not only on the national scientific community but also internationally was the latter one ${ }^{39}$. The successive international conferences on sleeping sickness, which meanwhile took place and in which Ayres Kopke participated as the representative of the Portuguese school, led to the medical mission to Entebbe, in Uganda, headed by Andrew Balfour (1873-1931). Belgium, the United Kingdom and Portugal participated in the mission ${ }^{40}$.

In the following year, the Portuguese mission, headed by Ayres Kopke, who was joined by two local doctors -Fontoura de Sequeira and Saraiva de Aguilar- arrived in Mozambique for the purpose of studying the geographic

38. This stamp, designed by Alberto Cutileiro, was issued to commemorate the Military Naval Club's centennial in 1966. Source: Museu das Comunicações, Lisboa.

39. Neves, Jaime. A Doença do sono, uma doença social. Anais da Escola Nacional de Saúde Pública e de Medicina Tropical. 1967; 1: 179-184.

40. Kopke, Ayres. Estudos Executados pela missão médica em Moçambique. Jornal da Sociedade das Sciências Médicas de Lisboa. 1928; 92 (9): 232-273. 
distribution of «African lethargy» in the equatorial and Eastern regions of this continent ${ }^{41}$. This mission was particularly important to Portugal to the extent that it strengthened the government's ties with major European imperial policies.

The last of the missions conducted during the period presently under study was undertaken by Luis Fontoura Sequeira in Portuguese Guinea. It explored this region in order to study the distribution of the vector agent involved in the spread of sleeping sickness ${ }^{42}$.

During the period studied, the Lisbon School of Tropical Medicine became a centre for teaching and specialized medical research invested in the fight against exotic diseases in the tropics and on the continent. The activity of the School reflects significant international collaboration and an attempt at constant revision with respect to the mapping of colonial endemic zones and to the fundamental research shared at national and international scientific meetings, despite the reduced number of participating researchers (see table 2). The network of scientific relations established by the Lisbon School of Tropical Medicine demonstrates the affiliation of the latter with the principal European schools, either through contacts established at the international meetings or through their active participation in the scientific missions undertaken in Africa.

Table 2. Participation of researchers of the Lisbon School of Tropical Medicine of Lisbon in missions and scientific congresses between 1902 and 1935

\begin{tabular}{ccccc}
\hline Date & Researchers & $\begin{array}{c}\text { International } \\
\text { Congresses }\end{array}$ & Scientific Missions & Study Visits \\
\hline 1904 & Ayres Kopke, Correia & Congress on Hygiene & S. Tome and Angola \\
& Mendes, Damas Mora, & \& Colonial Medicine \\
Silva Monteiro and & (Beriberi and Sleeping & Sickness) \\
& Bruto da Costa & & XV International \\
\hline 1906 & Ayres Kopke and & Congress of Medicine \\
& José de Magalhães & (Lisbon) \\
& & \multicolumn{3}{c}{} \\
\hline
\end{tabular}

41. Sant'Anna, Firmino. A Tripanosomíase humana na Rhodesia. Arquivos de Hygiene e Pathologia Exoticas. 1913; 4: 1-46.

42. Fraga de Azevedo, n. 18. 
Table 2. Participation of researchers of the Lisbon School of Tropical Medicine of Lisbon in missions and scientific congresses between 1902 and 1935 (continued)

\begin{tabular}{|c|c|c|c|c|}
\hline Date & Researchers & $\begin{array}{c}\text { International } \\
\text { Congresses }\end{array}$ & Scientific Missions & Study Visits \\
\hline 1907 & Ayres Kopke & $\begin{array}{l}\text { Congress on Hygiene and } \\
\text { Demography (Berlin) }\end{array}$ & $\begin{array}{c}\text { International Conference } \\
\text { on Sleeping Sickness } \\
\text { (London) }\end{array}$ & \\
\hline 1907 & $\begin{array}{c}\text { Correia Mendes, } \\
\text { Damas Moura, } \\
\text { Silva Monteiro, Bruto } \\
\text { da Costa } \\
\text { and others }\end{array}$ & & $\begin{array}{l}\text { Island of Principe } \\
\text { (Sleeping Sickness) }\end{array}$ & \\
\hline 1908 & Ayres Kopke & & $\begin{array}{c}\text { International } \\
\text { Conference on Sleeping } \\
\text { Sickness (London) } \\
\end{array}$ & \\
\hline 1909 & Ayres Kopke & $\begin{array}{c}\text { International } \\
\text { Congress on Medicine } \\
\text { (Budapest) }\end{array}$ & & \\
\hline 1910 & Ayres Kopke & $\begin{array}{c}\text { Congress on Colonial } \\
\text { and Tropical Agronomy } \\
\text { (London) }\end{array}$ & & \\
\hline 1911 & Silva Telles & $\begin{array}{c}\text { Universal Congress of } \\
\text { Races (Brussels) }\end{array}$ & & \\
\hline 1911 & Firmino Sant'Anna & & $\begin{array}{c}\text { Zambezia (Sleeping } \\
\text { Sickness) }\end{array}$ & \\
\hline 1913 & Ayres Kopke & $\begin{array}{l}\text { International Congress } \\
\text { of Medicine (London) }\end{array}$ & & $\begin{array}{c}\text { Schools of } \\
\text { Tropical Medi- } \\
\text { cine in London, } \\
\text { Paris, Hamburg } \\
\text { and Frankfurt }\end{array}$ \\
\hline 1923 & Ayres Kopke & $\begin{array}{c}\text { International Congress } \\
\text { on Tropical Medicine } \\
\text { (Rome) }\end{array}$ & & \\
\hline 1923 & Ayres Kopke & $\begin{array}{l}\text { 1st Congress on Tropical } \\
\text { Medicine in Western } \\
\text { Africa (Luanda) }\end{array}$ & & \\
\hline 1924 & $\begin{array}{l}\text { Ayres Kopke and } \\
\text { Silva Telles }\end{array}$ & $\begin{array}{l}\text { Conference of the } \\
\text { International Colonial } \\
\text { Institute (Rome) }\end{array}$ & & \\
\hline
\end{tabular}


Table 2. Participation of researchers of the Lisbon School of Tropical Medicine of Lisbon in missions and scientific congresses between 1902 and 1935 (continued)

\begin{tabular}{|c|c|c|c|c|}
\hline Date & Researchers & $\begin{array}{c}\text { International } \\
\text { Congresses }\end{array}$ & Scientific Missions & Study Visits \\
\hline \multirow[t]{3}{*}{1926} & Ayres Kopke & & International & \\
\hline & & & Conference on Sleeping & \\
\hline & & & Sickness (London) & \\
\hline \multirow[t]{2}{*}{1927} & Ayres Kopke and & & Mozambique (Sleeping & \\
\hline & Aníbal de Magalhães & & Sickness) & \\
\hline 1928 & Ayres Kopke & $\begin{array}{c}\text { Colonial Medical Days } \\
\text { (Paris) }\end{array}$ & $\begin{array}{c}\text { International Conference } \\
\text { on Sleeping Sickness } \\
\text { (Paris) }\end{array}$ & \\
\hline 1928 & $\begin{array}{l}\text { Alfredo Gomes da } \\
\text { Costa }\end{array}$ & $\begin{array}{l}\text { International Congress } \\
\text { on Tropical Medicine } \\
\text { and Hygiene (Cairo) }\end{array}$ & & \\
\hline 1930 & José de Magalhães & & $\begin{array}{l}\text { Study mission for the } \\
\text { collection of medical } \\
\text { research material }\end{array}$ & \\
\hline 1930 & Firmino Sant'Anna & & $\begin{array}{c}\text { Cape Verde } \\
\text { Demography and } \\
\text { Sanitation }\end{array}$ & \\
\hline 1931 & Froilano de Melo & $\begin{array}{c}\text { 2nd International } \\
\text { Congress of Paludism } \\
\text { (Algeria) }\end{array}$ & & \\
\hline 1931 & Ayres Kopke & $\begin{array}{c}\text { International } \\
\text { Mediterranean } \\
\text { Congress (Marseille) }\end{array}$ & & \\
\hline 1932 & Fontoura de Sequeira & & $\begin{array}{c}\text { Guinea } \\
\text { (Sleeping Sickness) }\end{array}$ & \\
\hline 1932 & Eurico de Almeida & $\begin{array}{l}\text { International Congress } \\
\text { on Tropical Medicine } \\
\text { and Hygiene (Cairo) }\end{array}$ & & \\
\hline
\end{tabular}

Based on our analysis of the two tables presented above, we conclude that Ayres Kopke was the most emblematic researcher of this School and of Portuguese Tropical Medicine in general during the period being studied, 
and the acknowledged leader of a research programme developed on the subject of sleeping sickness.

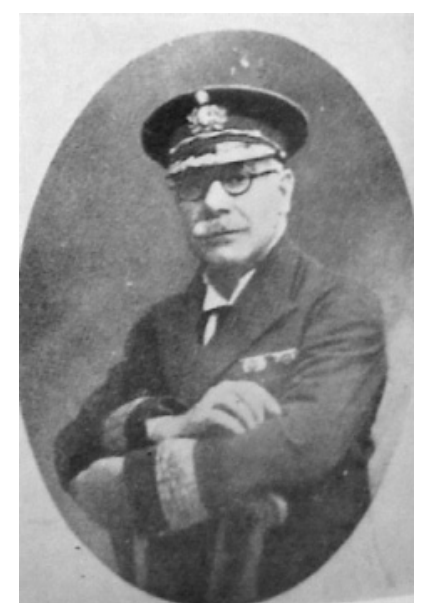

Figure 2. Ayres Kopke (1866-1944) ${ }^{43}$

In 1897, Kopke published a paper on malaria, referred to by Laveran in the Traité $d u$ Paludisme, published in 1907. In 1901, he undertook the Portuguese mission for the study of sleeping sickness in Angola, organized by Anibal Bettencourt (1868-1930), director of the Câmara Pestana Bacteriological Institute in Lisbon and headed the first bacteriological laboratory at the Naval School, where the first clinical analyses in the field of tropical diseases were carried out. In 1902, Kopke was nominated professor of Parasitology at the School of Tropical Medicine as well as director of its laboratory. From then on, he became the representative of the Lisbon School of Tropical Medicine at international scientific meetings and of Portugal in the commissions for the study of sleeping sickness. At the Fifteenth International Medical Congress held in Lisbon in 1906, Ayres Kopke defended the advantages of the use of Atoxyl in the treatment of chronic trypanosomiasis (caused by brucei gambiense Trypanosome), establishing specific doses for treatment. He demonstrated the efficacy of the 
treatment based on the observation of experimental data obtained from laboratory animals inoculated with the parasite, concluding that Atoxyl would be effective in the first phase of the disease ${ }^{44}$. These results were lauded by the international scientific community and in particular by Robert Koch (1843-1910), Alphonse Laveran, Paul Elrich (1854-1915), and Patrick Manson. The article which appeared in the Archivos de Hygiene e Pathologia Exóticas, in 1915, was later translated into English. This publication demonstrates the reputation of the School and the work therein developed in the area of European tropical medicine ${ }^{45}$.

According to the analyses undertaken, we can state that the School of Tropical Medicine in the period studied was in the main able to respond to tropical medicine as a new medical speciality, promoting its recognition as a factor of economic priority and Portuguese colonial politics, within the context of the Third Colonial Empire.

\subsection{Clinical activity}

When the Colonial Hospital was created, Portugal was struggling with the most difficult phase of occupation and pacification of the border areas of the overseas provinces. Given that the number of deaths caused by tropical diseases was greater than deaths in combat, the Portuguese government recognized the urgent need to provide medical assistance in the metropolis for the civil servants and soldiers returning from overseas.

As teaching the theory and practice of tropical medicine was amalgamated with the hospital, it seemed natural that both institutions should co-exist in the same place and under the same director. This teaching hospital was, at first, provisionally located in an eighteenth-century building belonging to the Ministry of Maritime Affairs ${ }^{46}$, the National Rope Factory (Cordoaria), where it remained until 1925. The teaching hospital

44. Kopke, Ayres. Traitement de la maladie du sommeil. XIVème Congrès d'Hygiène. Berlin: 1907, p. 299-347.

45. Kopke, Ayres. Traitement de quelques cas de trypanosomiase humaine par le Salvarsan et le Néosalvarsan. XVIlth International Congress of Medicine. London: 1913. p. 195-200. Ribeiro, Pedro. Ayres Kopke (1866-1944) and the dissemination of Portuguese research on tropical medicine in international meetings. Lisbon: STEP Meeting. Lisboa; 2000.

46. This building had been the site for the production of cables and sails for the Portuguese caravels since the sixteenth century. 
had a strong military presence: its director was a military doctor, and both the nursing services and assistant personnel were medically trained and worked in a Navy building.

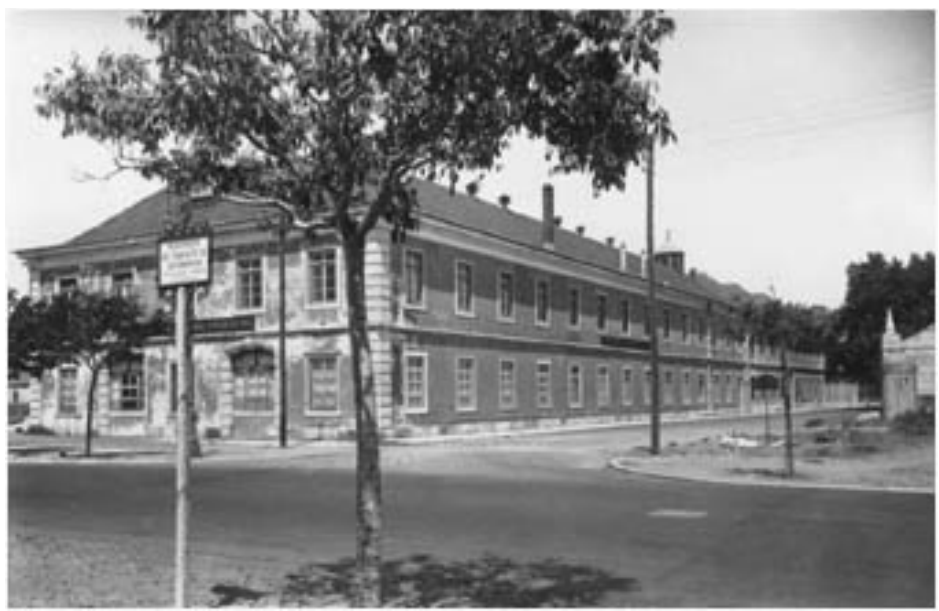

Figure 3. The building where the Colonial Hospital and the School of Tropical Medicine were situated in $1902^{47}$

In 1919, owing to the cramped working conditions, a farm was acquired where the hospital was to be newly situated, and where it remains still today. The new facilities included adaptations made to the existent buildings on the farm and were financed by the colony of Macau. A pavilion, bearing the name of the colony, was built for hospitalization and constituted the central body of the hospital until $1942^{48}$.

In the period studied, we can consider two phases in the life of this specialized medical institution, bearing in mind the number of patients, the

47. Photography obtained at the Central Archives of the Portuguese Navy.

48. However, after the reorganization of the health services of the Portuguese Empire in 1943, the interest in maintaining a hospital unit with the characteristics of the Colonial Hospital grew and culminated with the inauguration of the Overseas Hospital in 1957. The name of this hospital was changed in 1974 due to the transference of guardianship from the Ministry of Overseas Affairs to the Ministry of Health. It came to be known as the Egas Moniz Hospital, in homage to the Portuguese doctor who was awarded the Nobel Prize for Medicine and Physiology in 1949. 
quality of patient-assistance and the close relationship between teaching and research in the field of tropical medicine. The first two years correspond to a period of organization in hospital management; between 1904 and 1922, a phase of consolidation and growth can be noted; and finally, over the final 20 years of the period studied, there occurred a gradual decline in the importance of this public health unit, as can be seen in graph. 1.

\section{Graph. 1 - Representation of the number of patients hospitalized at the Colonial} Hospital between 1903 and $1935^{49}$

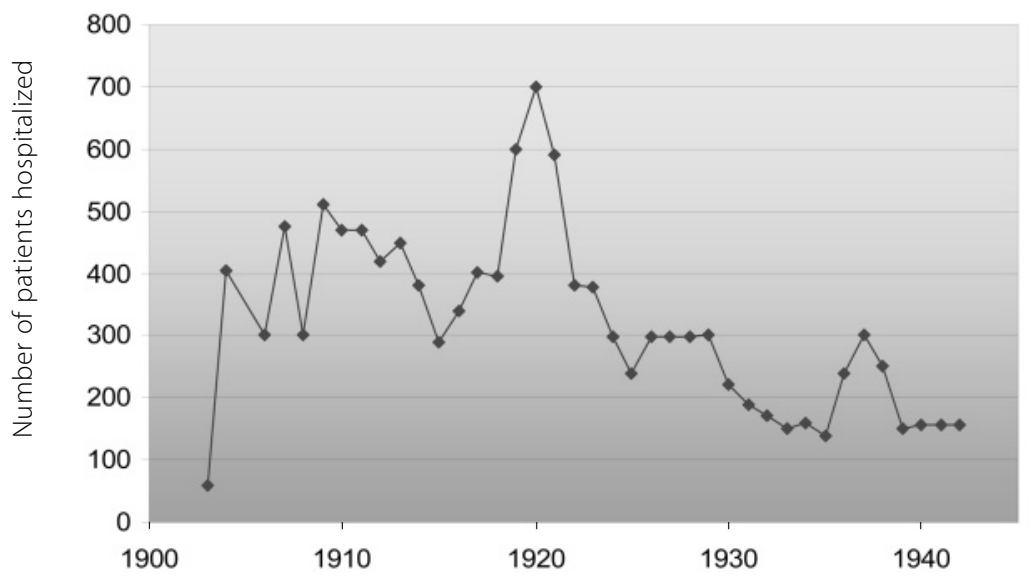

Notwithstanding its meagre logistical conditions (in comparison with similar institutions in Europe) during this first period (1904-1922), the high frequency of hospitalizations reflects the close collaboration existing between experimental research carried out at the laboratories and the effective clinical trials of therapeutic agents used on patients. At this time, the scientific research conducted by the teachers at the School of Tropical Medicine was internationally recognized and led to the establishment of international partnerships for the mapping, control and eradication of

49. Faria, João. O Hospital Colonial de Lisboa. Boletim clínico do Hospital Colonial e boletim estatistico. 1950. 
sleeping sickness ${ }^{50}$. The hospital thus served as a meeting-ground for scientific research, the establishment of an alliance between laboratory practice, and clinical experience.

In the following period, there is a successive decline in the admission of patients. This is closely related to the improvement of the means of control of exotic diseases overseas. On the one hand, the sequential knowledge of the vectors responsible for the transmission of diseases and of the means of propagation in human beings led to a significant improvement in the hygiene and epidemiological protocols both for the colonists and the colonised. On the other hand, progress made in tropical medicine led to an improvement of the settlement conditions for Europeans in their respective colonies. In the Portuguese case, the intersection of these two variables led to the reorganization of the health services, by creating hospital assistance in the colonies, which in turn made the demand for services from the Colonial Hospital to decrease in the metropolis. Yet, it also led to a greater specialization of the clinical staff there in response to the more complex cases that the colonial medical establishments could not resolve ${ }^{51}$.

In addition to this hospital, there were sanitary centres in the various Portuguese colonies headed by doctors who had specialized at the Lisbon School. These doctors were responsible for the organization of sanitary services in the colonies as well as a technical council to which were attributed specific tasks: the study of widespread diseases in the colonial provinces; development in the area of technical progress for the professionals involved (doctors, pharmacists, nurses); the implementation of means designed to finance the purchasing of laboratory equipment for research and treatment, and finally, the publication of specialized journals on tropical medicine in the colonies.

50. Ayres Kopke carried out laboratory tests with Atoxyl on patients hospitalized at the Colonial Hospital. See, for example, Kopke, Ayres. Trypanosomiasis Humaine. Archivos de Hygiene e Pathologia Exóticas. 1905; 1: 159-188.

51. The Colonial Hospital continued to be the key organ for medical assistance in the Portuguese Empire, especially in the 1930s. With the proclamation of the Colonial Act and the publication of the Organic Letter of the Portuguese Colonial Empire, Government Decree 18: 570, 8 July 1930, a strongly nationalistic and centralized juridical-institutional panel was established. 


\section{Some concluding remarks}

Tropical Medicine emerges in the European context as a consequence of political, cognitive and ideological factors. First, there is the effective control of the colonies through a minimization of the risks of contagion by diseases hitherto unknown in Europe, which had decimated entire populations of settlers. Secondly, there is the establishment of a new conceptual framework for the understanding of the nature of disease and the attendant emergence of a new scientific discipline. Thirdly, there is evidence of a certain appropriation of the positivist ideals.

At the beginning of the nineteenth century, Portugal lived under the motto of sanitary reform inaugurated by Ricardo Jorge (1858-1939) ${ }^{52}$. In this context, tropical medicine emerges as a result of the attempt at scientific specialization in the face of generalist medicine, bearing the same weight as experimental science and the medical apostolate ${ }^{53}$, and further still, of the affirmation of political power in the Portuguese colonies.

From the analysis of table 1, we can perceive how research at the school attempted to respond to the demand for affirmation of a new medical investigation area, in the domain of overseas scientific exchange not only in the realm of the European community but also in the colonies. The axis of dialogue between Europe and its colonies was crucial both to the acknowledgment of the medical speciality and to the definition of parameters for the valorisation of tropical medicine as an important factor in the history of the Third Portuguese Colonial Empire. The activity in the school reflects an intense international collaboration and an attempt to foster continuous modernization, in terms both of the mapping of endemic colonial zones and basic research, divulged both in national and international science conferences. The network of scientific relations established by the Lisbon

52. Ricardo Jorge was a Portuguese physician and professor at the Medical School of Oporto. In 1884 he published the book entitled Higiene social aplicada à nação Portuguesa (social hygiene applied to the Portuguese nation), and became a pioneering organiser of Portuguese public health services according to modern hygiene precepts.

53. This scientific apostolate is clearly spread by Celestino da Costa, one of the most emblematic figures of the modernization of medical teaching in Portugal in the first decades of the twentieth century. For his interventions in the Council of National Education, together with his disciples' and with his partners' at the University, see Amaral, Isabel. A escola de Histofisiologia de Augusto Celestino da Costa (1911-1956). Actas do 10 Congreso Luso-Brasileiro de História da Ciência e da Técnica. Évora: Universidade de Évora; 2000. p. 615-629. 
School of Tropical Medicine exhibits a clear institutional alignment with the main European schools of the time not only through the contacts undertaken in international meetings but also through active participation in scientific missions in Africa.

The scientific missions undertaken between 1902 and 1935 by the Lisbon School of Tropical Medicine contributed to the enrichment of the European colonial discourse, which relied on tropical medicine as an instrument for colonization. It is sleeping sickness, as a characteristic and widespread African disease, that best typifies the need for multidisciplinary approaches to health crises and challenges, which in turn highlights the increasing need of greater discipline-specific fundamental research practices in medicine by the first half of the twentieth century. The missions carried out on the Island of Principe permitted the establishment of a concerted programme in the fight against sleeping sickness supported by specific drug therapies. Buttressed by the results of the research group led by Ayres Kopke from the Lisbon School of Tropical Medicine, and allied with effective sanitation intervention, this Lisbon-based medical community was internationally recognized and acknowledged.

The mission undertaken in Mozambique exemplifies the international exchanges of ideas abetting the establishment of suitable plans of action in order to consolidate colonial hegemony. The Portuguese doctors who fulfilled tasks there were also in service to other countries interested in the colonised territories and developed research, albeit of lesser relevance, thus contributing to the international scientific community.

The contribution of the scientific missions implemented under the aegis of the Lisbon School of Tropical Medicine privileged the ideological programme inherent within any analysis of the rhetoric of colonial policies: to explore, investigate, intervene, administrate, and colonize. The doctors' active role, as can be seen in these missions, significantly contributed to the «civilizing» work of the country, be it through the protection of Europeans who were to settle in the colonies or through the provision of therapeutic, sanitary and hygienic life-preserving and life-prolonging benefits for the indigenous populations, conceivably one of the most notable ways of proving the colonizers' «superiority».

The colonial hospital developed an alliance strategy between scientific research and clinical practice. This teaching hospital provided Portuguese tropical medicine with a hegemonic and singular position vis-à-vis other hospital institutions existing in Portugal throughout the historical period 
we have here examined. It thus participated in the movement of scientific specialisation called for by the Humboldt reform in Germany, in 1809, which had advocated for an alignment with other European countries. The field of tropical medicine as a fully independent, scientific area had at last come of age.

The acknowledgment of the benefits of such an institution by the Portuguese government is directly linked, on the one hand, to developments in Portuguese colonial politics, and, on the other, to the consolidation of tropical medicine as the foundation for all future clinical practices: both essential elements for the advancement of the colonial project, i.e., «Everything for the Empire's sake».

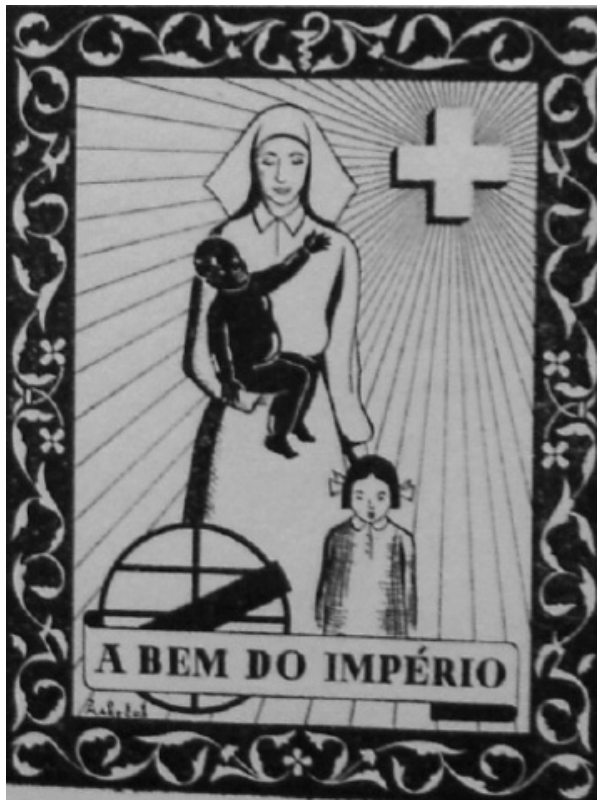

Figure 4. Logotype of the Colonial Hospital Clinical and Statistical Bulletin

The Lisbon School of Tropical Medicine, founded a few years after the English schools of tropical medicine, played a similar role to that of its counterparts in the use of medicine as an ideological instrument for colonisation. Serving as a teaching and research centre, the Portuguese school 
propelled several figures onto the international stage, having contributed in a significant way to the medical missionary vision that was so pivotal to the positivist conception of the intellectual elite during the first decades of the twentieth century. It is this pragmatic and positivist position that lies at the heart of the colonial project of the Third Portuguese Empire: «civilize in order to conquer».

Therefore, tropical medicine emerged both as a medical speciality developed between the metropolis and the colonies and as a new locus of continuous dialogue between science and the economic and political interests of Portugal and the other European countries with which it shared the African territories. In this geo-political space, the School of Tropical Medicine and the Colonial Hospital of Lisbon played a major role along with its European counterparts between 1902 and 1935. And it is this international participation which has driven our analysis of the specialization of medicine in the imperial context.

The success on a national level of the Portuguese appropriation of a part of the African territorial space cannot be compared with the results obtained by other European countries due to latter's greater cultural, economic and political dimensions. Portugal entered the dispute for Africa under fragile conditions, both in political and economic terms, which from the first conditioned the advantages it eventually derived from its colonial enterprise. Nevertheless, if we consider Portugal's contributions with respect to the history and development of tropical medicine, then we may conclude that it promoted the cognitive development of medical disciplines and followed closely the political agenda carried out in the rest of Europe. Although it belongs to the historical decline of a once-great maritime Empire, the history of tropical medicine in Portugal cannot be separated from the context of neighbouring European histories. Furthermore, it participated in the emergence and consolidation of tropical medicine by way of the creation of specialized institutions (school and hospital), where scientific and clinical research could give rise to this new disciplinary area significantly enriched by major Portuguese contributions. 